India's Food Security Strategy and its Impact on the Food Surplus State of Punjab

\author{
Veena Goel \\ Sr. Economist (Marketing) \\ Department of Economics, \\ Punjab Agricultural University \\ Ludhiana - 141004, India \\ Email Address: veengl@yahoo.com
}

Phone No. 0161401960 ext.301

Contact author: Veena Goel

Topic: Food Chain Approach 


\title{
India's Food Security Strategy and its Impact on the Food Surplus State of Punjab
}

\begin{abstract}
Based upon both primary data obtained from farmers and secondary data from government publications and websites this study examines the country's food security status, role of domestic food production to enhance national food security and its impact upon the agricultural sector in the surplus agrarian region state Punjab. Study indicated that the poverty level continues to persist high and it varies across regions. Public Distribution System constitutes a key element of food security in the country. It has come rely upon internal procurement with the widespread dissemination of green revolution technology accompanied by a supportive policy framework. Government procures both wheat and rice from the surplus regions to feed the PDS. The state of Punjab has emerged a major contributor for both these crops. As this has heavily tilted the cropping patterns towards these crops farmers have come to face several environmental problems particularly of water depletion. Due to low socio economic profiles and the lack of adequate market infrastructure farmers are unable to bring large-scale shifts in their cropping patterns. Thus it has endangered farmers' own food security that may a new dimension to food security in these countries.
\end{abstract}

Key Words: Poverty, food security, food grain procurement, public distribution system.

\section{Introduction}

World Food Summit (WFS) defined food security as a situation that exists when 'all people at all times have physical and economic access to sufficient, safe and nutritious food to meet their dietary needs and food preferences for an active and healthy life' (FAO 1996). Of its several interrelated dimensions, food availability and access to food are the most common defining characteristics. Food security has been examined at the global, regional, national, household and individual levels. According to FAO estimates number of undernourished people during 2001-03 stood at 854 million (820 million in the developing, 25 million in the transition and 9 million in the industrialized countries) (FAO 2006). Food insecurity can either be short term e.g. a famine from crop failure or long term under nutrition i.e. chronic. Chronically poor experience multiple deprivations over a long period (Radhakrishna et. al 2007). Estimates of chronic poverty vary between 300 and 422 million, of which nearly half are in South Asia and one-third in India (Hulme, Moore and Shepherd 2001). Based on a country specific situation causes, nature and the magnitude of food security can differ between countries (Lutz 2000; USDA 1998; Masika, Haan and Baden 1997). Thus each nation needs to adopt a 
strategy consistent with its resources and capacities to tackle the problems of hunger and food insecurity.

National Food Security refers to a nation's capacity to ensure household/individual food security without undue departure from other policy goals. It is a position when a country achieves self sufficiency in the production of staple foods or has the financial resources to import such staples (FAO 2000). However, some level of domestic production ensures against risks such as import interruptions and poor harvests in exporting countries. NFS can be monitored in terms of demand and supply indicators (Barun et al.1992). Adequate food supply can ensure greater food security but it is not necessarily so, because poverty and chronic malnutrition exist even in countries with a food surplus. Notwithstanding substantial increases in global food production in the last 50 years, food security as determined by access to food with essential nutrients and inequalities in food entitlements continues to present major hurdles (Pretty, Thompson and Hinchcliffe 1996). Thus, the challenge is not only to increase food production but also to ensure that all sections of the population have an access to food that satisfies essential nutritional requirements. Subsistence production needs to be increased while cash income, savings and investments should also grow that implies more reliance on markets and production must also be responsive to changing urban market demand (Hulse 1999). Despite this, it has been recognized that to achieve food security at the household and individual levels it is important to realize food security at the national level. Increased food availability is a necessary condition for achieving food security in food deficit countries (George 1999). Household food security has been defined as an access to food that is adequate in terms of quality, quantity, safety and cultural acceptability for all the household members (Gillespie and Mason 1991 quoted in Nawani 1994).

As most of the world's food insecure live in the rural areas and rural residents even those who are not farmers, are dependent on employment and income generated through agricultural activities. This necessitates a special emphasis on agricultural and rural development. Thus, public policy in most low income developing countries focuses on increasing food production and ensuring better access to food through generating agricultural development and job opportunities in the agricultural sector (OECD 2000; 
Scherr 1995). Like other developing countries, food security concerns are of utmost importance in India as well because a large percentage of its population is poor. Agriculture sector has an important role to play as about $70 \%$ of her population depends heavily on this sector for its livelihood and income. So this study has been carried out to examine the poverty dimensions in the country, measures adopted by the national government to enhance staples' production to mitigate food security and its impact upon the cropping pattern in the surplus agrarian state of Punjab.

\section{Data Base}

The study is based upon both primary and secondary data. Secondary data have been obtained from the government publications such as Economic Surveys, Agricultural Statistics at a Glance, Department of Food and Public Distribution and the Statistical Abstract of Punjab. Primary data have been obtained through interviews held with farmers during the various research projects and peers..

\section{Results and Discussions}

\section{Poverty Status}

At the time of independence, the country faced twin nutritional problems - threat of famine and acute starvation, and chronic under nutrition. Former existed due to the lack of national and regional food security systems. The latter existed due to low dietary intakes because of lack of purchasing power among poorer segments of the population. For the measurement of poverty monetary cut-offs could be fixed in terms of either income or expenditure, however, expenditure is comparatively more stable than income over time. So, consumption expenditure has been considered more appropriate and relevant measure of the level of poverty (Joshi 1997).

Planning Commission has defined the poverty line in terms of monthly per capita consumption expenditure (MPCE). And, the most commonly used poverty index is 'Head Count Ratio' (HCR) that refers to the proportion of total population falling below the poverty line. MPCE at 1973-74 prices (table1) corresponding to a calorie intake of 2400 for the rural and 2100 for the urban areas stood at Rs. 49.63 and Rs. 56.96. Updated by suitable price indices to ensure the same purchasing power MPCE during 2004-05 gradually increased to Rs.356.30 for the rural and Rs. 538.60 for the urban areas. However, these poverty lines that met nutritional norms in the base year do not directly 
Table 1: Poverty Lines and Poverty Estimates in India

\begin{tabular}{lcccccccc}
\hline Year & \multicolumn{2}{c}{$\begin{array}{c}\text { Poverty Lines } \\
\text { (Rs.) }\end{array}$} & \multicolumn{2}{c}{ Poor (Millions) } & \multicolumn{3}{c}{ Poverty Ratios (\%) } \\
\cline { 2 - 9 } & Rural & Urban & Rural & Urban & Comb & Rural & Urban & Comb \\
\hline $1973-74$ & 49.63 & 56.96 & 261.00 & 60.00 & 321.00 & 56.40 & 49.00 & NA \\
$1977-78$ & 60.60 & 69.90 & 264.00 & 65.00 & 329.00 & 53.10 & 45.20 & 51.30 \\
$1983-84$ & 101.80 & 117.50 & 251.96 & 70.94 & 322.90 & 45.65 & 40.79 & 48.40 \\
$1987-88$ & 131.80 & 152.10 & 232.00 & 75.00 & 307.00 & 39.10 & 38.20 & 38.86 \\
$1993-94$ & 205.84 & 281.35 & 244.03 & 76.34 & 320.37 & 37.27 & 32.36 & 36.00 \\
$1999-00$ & 327.60 & 454.11 & 193.24 & 67.01 & 260.27 & 27.09 & 23.62 & 26.10 \\
$2004-05$ & 356.30 & 538.60 & 220.92 & 80.80 & 301.72 & 28.30 & 25.70 & 27.50 \\
$2004-05^{*}$ & & & 170.30 & 68.20 & 238.50 & 21.80 & 21.70 & 21.80 \\
$2006-07^{* *}$ & NA & NA & 170.50 & 49.60 & 220.10 & 21.10 & 15.10 & NA \\
\hline
\end{tabular}

* Estimates based on MRP method, **Projections of the $10^{\text {th }}$ Plan

Source: Antony and Laxmaiah 2008, 10th Five Year Plan (Volume I).

reflect nutritional adequacy and food security (Antony and Laxmaiah 2008). At these poverty lines HCR fell from $56.40 \%$ to $39.10 \%$ for the rural and $49.00 \%$ to $38.20 \%$ for the urban areas during the period 1973-74 to 1987-88. With the initiation of market reforms, HCR rose marginally for the rural (41.7\%) while declined for the urban (37.8\%) areas during 1992-93. Thereafter it again started declining and stood at $28.30 \%$ for the rural and $25.70 \%$ for the urban areas during 2004-05. Likewise, number of poor either in the rural and urban areas do not depict any uniform pattern of movement over time. However, number of poor during 2004-05 compared to 1973-74 declined in the rural areas (261 to 220 million) while increased in the urban areas (60 to 80.8 million). $61^{\text {st }}$ round of the National Sample Survey Organization (NSSO) based upon consumption distributions contained two different estimates. First is from consumer expenditure data collected using a 30 day recall period for all the items, called Uniform Recall Period (URP). Second is from data collected using a 365-day recall period for the five non food items, i.e. clothing, footwear, durable goods, education and institutional medical expenses while a 30-day recall period for the remaining items, called Mixed Recall Period (MRP) (GOI 2007). Percentage of poor estimated from URP method stood at $28.30 \%$ for the rural and $25.70 \%$ for the urban areas while the number of poor estimated from MRP method stood at 170.30 million for the rural and 68.20 million for the urban areas. These estimates are roughly comparable to the poverty estimates of 1999-2000. Most of the 
rural poor comprise of daily wage earners, self-employed householders and landless labourers.

There exist wide disparities in the incidence of poverty across the states (Goel 2009). During 2004-05 (based upon MRP its incidence stood above 30\% for six states, namely, Orissa (39.90\%), Jharkhand (34.80\%), Bihar (32.50\%), Madhya Pradesh (32.40\%), Chhattisgarh (32\%) and Uttarakhand (31.80\%); ranged from $20 \%$ to $30 \%$ for three states, namely, Uttar Pradesh (25.50\%) Maharastra (25.20\%) and West Bengal (20.60\%); ranged from $10 \%$ to $20 \%$ for nine states, namely, Tamil Nadu (17.80\%), Rajasthan (17.50\%), Karnataka (17.40\%), Assam (17\%), Gujarat (12.50\%), Goa (12\%), Kerala (11.40\%), Andhra Pradesh (11.10\%) and Delhi (10.20\%) while lied below 10\% for the four states, namely, Haryana (9\%), Himachal Pradesh (6.70\%), Punjab (5.20\%) and Jammu \& Kashmir (4.20\%). The nine states having incidences of poverty above $20 \%$ also had the incidence of rural poverty above $20 \%$. Among these states, absolute poverty stood above 20 million people in the states of Uttar Pradesh (45.82 million), Bihar (29 million), Maharashtra (25.98 million) and Madhya Pradesh (21.10 million) while lied from 10 to 20 million for the remaining five states, viz. West Bengal (17.32), Orissa (15.35), Tamil Nadu (11.51), Rajasthan (10.72) and Jharkhand (10.04). Rural poverty for the former four states stood at 35.77, 26.29, 12.84 and 14.20 millions while for the latter five at 14.66, 12.92, 5.65, 6.67 and 8.98 millions. In comparison, urban poverty stood above 10 million people only for the states of Maharashtra (13.14) and Uttar Pradesh (10.05) (Ibid.). Such a skewed pattern in the incidence of poverty exists because the process of agricultural development in the country is not uniformly distributed in the country (Prakash and Goel 1986).

\section{Food Security}

\section{Household Food Security}

Cereals being the most important source of energy its adequate availability can go a long way in reducing hunger and poverty while ensuring food and nutrition security (Nawani 1994). Inter-Ministerial Working Group set up in the Ministry of Agriculture on the basis of average net production of cereals for three years i.e. during 1991-93 observed that cereals alone provide per capita per day $1501 \mathrm{kcal}$ of energy and 37.4 gms of protein 
that constitutes about $68 \%$ of the total energy and $74.8 \%$ of the total protein requirements (Ministry of Agriculture 1994).

To ensure food grain entitlements at affordable prices, public distribution system (PDS) constitutes a key element of the food security system. It is the largest distribution network that functions through a net- work of fair price shops (FPSs). It aims at supplementing the supply of food grains particularly to the vulnerable sections of the population at subsidised prices. It is operated under the joint responsibility of the Central and State governments. Central government is responsible for the procurement, storage, transportation and bulk allocation of food grains, etc. State governments are responsible for the distribution of food grains to consumers, its allocation between the rural and urban poor, identification of poor families, issuance of ration cards, supervision and monitoring the functioning of FPSs. The PDS that existed till 1992 was a general entitlement scheme for all consumers without specific targets (Singh, 2006). With reforms in agriculture that began in the mid-eighties, revamped PDS was launched from January 1992 in about 1752 blocks falling in the drought prone, desert, integrated development project and certain designated hill areas. After the WTO treaty, it was replaced by the Targeted PDS from June, 1997. Thereafter, a distinction has been drawn between the 'Below Poverty Line (BPL) and 'Above Poverty Line' (APL) families. The CIPs have been fixed at $50 \%$ and $90 \%$ of the economic cost for the BPL and APL families.

\section{National Food Security}

During the Post Independence Period, with the inception of planning a number of policy measures were initiated to increase NFA of the major staples, i.e. wheat and rice. Earlier Five Year Plans enshrined land reforms and massive investments in irrigation infrastructure to augment domestic production. However, internal procurement remained relatively dormant due to low domestic production and the lack of adequate infrastructure. So, shortages in food grain availability were mitigated through heavy reliance on wheat imports under PL 480 from USA. With the adoption of green revolution technology since the mid-60s earlier for wheat and later for paddy thrust shifted to internal procurement. Thereafter, PDS has been linked with procurement to provide support prices to the producers. The strategy of providing subsidized agricultural inputs such as fertilizer, power, irrigation, credit and the announcement of minimum 
support/procurement prices (MSPs) have led to a widespread dissemination of the green revolution technology. As a result, availability of food grains in the country has consistently increased from 52.4 million tonnes (comprising of 44.3 million tonnes cereals and 8 million tonnes of pulses) during 1951 to about 181.70 million tonnes during 2006 after a brief respite during 2005. Concomitantly, dependence upon cereal imports had declined during the early 70 s while completely diminished thereafter. Government however resorts to imports/exports of these cereals only when domestic shortages/surpluses emerge.

An examination of per capita net availability of food grains (table 2) indicates that

Table 2: Net Availability of Food grains (per capita grams/day) in India from 1951

\begin{tabular}{ccccc} 
Year & $\begin{array}{c}\text { Food } \\
\text { grains }\end{array}$ & $\begin{array}{c}\text { Cereals Share } \\
\text { in } \\
\text { Food grains }(\%)\end{array}$ & $\begin{array}{c}\text { Wheat \& Rice } \\
\text { Share in } \\
\text { Cereals }\end{array}$ & $\begin{array}{c}\text { Gram } \\
\text { Share in } \\
\text { Pulses }\end{array}$ \\
\hline 1951 & 394.90 & 84.63 & 67.21 & 37.07 \\
1956 & 430.70 & 83.68 & 69.15 & 41.25 \\
1961 & 468.70 & 85.28 & 70.10 & 43.77 \\
1966 & 408.10 & 88.19 & 71.49 & 37.97 \\
1971 & 468.80 & 89.08 & 70.93 & 39.06 \\
1976 & 424.30 & 88.10 & 71.35 & 40.00 \\
1981 & 454.80 & 91.75 & 78.46 & 35.73 \\
1985 & 453.40 & 91.60 & 78.83 & 33.86 \\
1990 & 472.60 & 91.30 & 79.88 & 26.03 \\
1991 & 510.10 & 91.84 & 82.92 & 32.21 \\
1992 & 468.80 & 92.68 & 86.44 & 29.45 \\
1993 & 464.10 & 92.20 & 79.76 & 29.56 \\
1994 & 471.20 & 92.11 & 84.54 & 31.72 \\
1995 & 495.50 & 92.35 & 85.82 & 39.42 \\
1996 & 475.20 & 93.12 & 85.97 & 34.56 \\
1997 & 503.10 & 92.63 & 84.36 & 33.42 \\
1998 & 447.00 & 92.66 & 84.93 & 40.85 \\
1999 & 465.70 & 92.16 & 85.21 & 40.00 \\
2000 & 454.40 & 93.02 & 86.04 & 33.96 \\
2001 & 416.20 & 92.79 & 84.49 & 26.67 \\
2002 & 494.10 & 92.84 & 86.18 & 30.23 \\
2003 & 437.60 & 93.35 & 88.57 & 29.21 \\
2004 & 462.70 & 92.26 & 83.77 & 31.28 \\
2005 & 422.40 & 92.54 & 84.83 & 33.65 \\
2006 & 445.30 & 92.70 & 85.34 & 32.92 \\
$2007(\mathrm{P})$ & 439.30 & 93.31 & 86.09 & 40.48 \\
\hline
\end{tabular}

Source: Agricultural Statistics at a Glance, 
it increased from 394.90gms/day during 1951 to $439.30 \mathrm{gms} /$ day during 2007 though in a fluctuating manner. It stood the highest being as high as $510.10 \mathrm{gms} /$ day during 1991 . Share of cereals in food grain availability increased from $84.63 \%$ during 1951 to $89.08 \%$ during 1971 but declined to $88.10 \%$ during 1976 . Thereafter, it increased again and came closer to $92 \%$ but remained below it during the 80 s while touched it during the $90 \mathrm{~s}$ and has remained consistently marginally above it since then. Share of the major staples i.e. wheat and rice in cereals stood as high as $67.21 \%$ during 1951, it touched $70 \%$ during 1961, increased further and came closer to $80 \%$ during 1990 while has hovered around $85 \%$ since then.

This indicates that per capita availability of food grains has increased over time. Within food grains it has, however, increased for the cereals while declined for the pulses sub group, recently, it has also declined for cereals though stood higher to the base period (Goel 2009). Further, within food grains share of cereals particularly of wheat and rice has accentuated. On the other hand, within pulses sub group share of grams stood at $37.07 \%$ during 1951 that increased to $40.48 \%$ during 2007, but it has kept fluctuating and ranged from about 26\% during 1991 to $43.77 \%$ during 1961.

The Food Corporation of India (FCI), a central agency, with the support of state agencies makes procurement of wheat and rice from surplus regions in the country. Besides, rice is also procured under a statutory levy imposed by the state governments on millers and wholesale dealers and varies across states. For example, statutory levy is 50\% in Andhra Pradesh (AP), 75\% in Punjab and Haryana, 60\% in Western Uttar Pradesh, $40 \%$ in some districts in Eastern UP, etc. Some state governments also impose restrictions on paddy movement outside the state to maximize procurement of paddy/rice. Procured grains are allocated to the state governments at the central issue prices (CIPs) while state governments fix the retail prices after taking into account transportation cost, dealers' commission, etc.

\section{Cereals Procurement}

An examination of cereals procurement (table 3) indicates that its quantity (comprising of wheat and rice) increased from 12.21 million tonnes during 1980-81 to 37.18 million tonnes during 2007-08 showing an increase of $204.50 \%$. During this period, procurement of these cereals declined during 1995-96 (10.82\%), 2002-03 
(17.03\%) and 2006-07 (19.11\%). Movement patterns of the wheat and rice procurement are not always in the same direction. Share of wheat in total procurement stood at $45.95 \%$ during 1980-81 but it has gradually increased and touched 70.07\% during 2007-08. This has been accompanied by a corresponding decline in the share of rice in procurement.

Table 3: Procurement of Food grains in India

\begin{tabular}{|c|c|c|c|c|c|c|c|c|}
\hline \multirow[t]{2}{*}{ Year } & Cereals & Rice & Wheat & Cereals & Rice & Wheat & Rice & Wheat \\
\hline & \multicolumn{3}{|c|}{ Absolute (Million tones) } & \multicolumn{3}{|c|}{ Change $(\%)$} & \multicolumn{2}{|c|}{ Shares $(\%)$} \\
\hline 1980-81 & 12.21 & 5.61 & 6.60 & --- & --- & --- & 45.95 & 54.05 \\
\hline $1985-86$ & 20.42 & 9.88 & 10.54 & 67.24 & 76.11 & 59.70 & 48.38 & 51.62 \\
\hline $1990-91$ & 20.42 & 12.67 & 7.75 & 0.00 & 28.24 & -26.47 & 62.05 & 37.95 \\
\hline $1995-96$ & 18.21 & 10.05 & 8.16 & -10.82 & -20.68 & 5.29 & 55.19 & 44.81 \\
\hline 1996-97 & 21.13 & 12.97 & 8.16 & 16.04 & 29.05 & 0.00 & 61.38 & 38.62 \\
\hline $1997-98$ & 24.89 & 15.59 & 9.30 & 17.81 & 20.23 & 13.96 & 62.64 & 37.36 \\
\hline 1998-99 & 25.25 & 12.60 & 12.65 & 1.46 & -19.19 & 36.09 & 49.90 & 50.10 \\
\hline 1999-00 & 32.37 & 18.23 & 14.14 & 28.20 & 44.68 & 11.79 & 56.31 & 43.69 \\
\hline 2000-01 & 37.64 & 21.28 & 16.36 & 16.26 & 16.75 & 15.63 & 56.54 & 43.46 \\
\hline $2001-02$ & 42.76 & 22.13 & 20.63 & 13.61 & 3.98 & 26.14 & 51.75 & 48.25 \\
\hline $2002-03$ & 35.48 & 16.42 & 19.05 & -17.03 & -25.79 & -7.64 & 46.29 & 53.71 \\
\hline 2003-04 & 38.63 & 22.83 & 15.80 & 8.89 & 39.01 & -17.07 & 59.10 & 40.90 \\
\hline 2004-05 & 41.48 & 24.68 & 16.80 & 7.38 & 8.13 & 6.29 & 59.51 & 40.49 \\
\hline $2005-06$ & 42.44 & 27.66 & 14.79 & 2.32 & 12.04 & -11.97 & 65.16 & 34.84 \\
\hline 2006-07 & 34.33 & 25.11 & 9.23 & -19.11 & -9.22 & -37.6 & 73.13 & 26.87 \\
\hline $2007-08$ & 37.18 & 26.06 & 11.13 & 8.31 & 3.78 & 20.62 & 70.07 & 29.93 \\
\hline 2008-09 & NA & NA & 22.23 & & & 99.72 & & \\
\hline
\end{tabular}

*Wheat marketing season- April to March, Rice marking season-October to September Source: Economic Surveys.

Government agencies procure wheat and paddy (unhusked rice) at the MSPs. These prices for both the crops are announced for each marketing year by the central government on the recommendations of the Commission for Agricultural Costs and Prices (CACP). These prices are based upon the cost of production and other factors that ensure remunerative returns to farmers. An examination of the MSP (table 4) indicates that these have gradually moved upwards both for paddy and wheat, however, percentage increases in these prices are not always uniform. Prior to 1997-98, government withdrew a distinction between the fine and superfine varieties of paddy and the separate MSPs were announced for each. 
Table 4: Minimum Support Prices of Paddy and Wheat

\begin{tabular}{|c|c|c|c|c|c|c|}
\hline \multirow[t]{3}{*}{ Crop } & \multicolumn{2}{|c|}{ Paddy } & \multirow[t]{2}{*}{ Wheat } & \multicolumn{2}{|c|}{ Paddy } & \multirow[t]{2}{*}{ Wheat } \\
\hline & Common & Grade 'A' & & Common & Grade 'A' & \\
\hline & \multicolumn{3}{|c|}{ Absolute (Rs/qtl) } & & Change (\%) & \\
\hline $1975-76$ & 74 & --- & 105 & --- & --- & --- \\
\hline $1980-81$ & 105 & --- & 130 & 41.89 & --- & 23.81 \\
\hline $1985-86$ & 142 & --- & 162 & 35.24 & --- & 24.62 \\
\hline $1990-91$ & 205 & --- & 180 & 44.37 & --- & 11.11 \\
\hline $1991-92$ & 230 & --- & 210 & 12.20 & --- & 16.67 \\
\hline $1992-93$ & 270 & --- & 250 & 17.39 & --- & 19.05 \\
\hline 1993-94 & 310 & --- & 305 & 14.81 & --- & 22.00 \\
\hline $1994-95$ & 340 & --- & 350 & 9.68 & --- & 14.75 \\
\hline $1995-96$ & 360 & --- & 360 & 5.88 & --- & 2.86 \\
\hline 1996-97 & 380 & --- & 380 & 5.56 & --- & 5.56 \\
\hline $1997-98$ & 415 & 445 & 475 & 9.21 & & 25.00 \\
\hline 1998-99 & 440 & 470 & 510 & 6.02 & 5.62 & 7.37 \\
\hline 1999-00 & 490 & 520 & 550 & 11.36 & 10.64 & 7.84 \\
\hline 2000-01 & 510 & 540 & 580 & 4.08 & 3.85 & 5.45 \\
\hline 2001-02 & 530 & 560 & 610 & 3.92 & 3.70 & 5.17 \\
\hline $2002-03$ & 550 & 580 & 620 & 3.77 & 3.57 & 1.64 \\
\hline 2003-04 & 550 & 580 & 630 & --- & --- & 1.61 \\
\hline 2004-05 & 560 & 590 & 630 & 1.82 & 1.72 & 0 \\
\hline $2005-06$ & 570 & 600 & 640 & 1.79 & 1.69 & 1.59 \\
\hline 2006-07 & $580 *$ & $610 *$ & $650 \#$ & 1.75 & 1.67 & 1.56 \\
\hline 2007-08 & $645 * *$ & $675^{* *}$ & 750\#\# & 11.21 & 10.66 & 15.38 \\
\hline 2008-09 & & & 1080 & & & 44.00 \\
\hline
\end{tabular}

Note: *Additional incentive bonus of Rs. 40/qtl on procurement till 31.03.2007

**Additional incentive bonus of Rs. 100/qtl for the entire season, \# Additional incentive bonus of Rs. 50/qtl. \#\# Additional incentive bonus of Rs. 100/qtl for the entire season;

Source: Department of Food and Public Distribution (Annual Reports)

\section{State wise Contribution}

Contribution to the central pool in procurement from the major states (table 5) indicates that during the period from 1996-97 to 2007-08/2008-09 combined average share of major five states, namely, Punjab, Andhra Pradesh, Haryana, Uttar Pradesh and Chattisgarh stood at 82.99 per cent for rice while of the three states, namely, Punjab, Haryana and Uttar Pradesh stood at 94.02 per cent for wheat. Values of the CV indicate 
that these states have remained the consistent contributors towards the central pool for procurement both for rice and wheat. Among these states, share of the state of Punjab both for rice and wheat stood the highest and remained comparatively stable. It has been followed by the state of Andhra Pradesh for rice while Haryana for wheat. Average shares during 1996-97 to 2007-08/2008-09 for these states for rice stood at $35.51 \%$ for Punjab and $25.52 \%$ for Andhra Pradesh while for wheat at $57.80 \%$ for Punjab and $27.88 \%$ for Haryana. This indicates that share of the state of Punjab has remained the largest. However, it has recently declined both for wheat and rice. In comparison, share of the state of Andhra Pradesh has increased for rice while of Haryana for wheat. Among the other states, share of Haryana has recently steeply declined for rice and Uttar Pradesh for wheat however share of Uttar Pradesh has again picked up for rice..

Table5: Shares (\%) of Major States in Public Procurement

\begin{tabular}{|c|c|c|c|c|c|c|c|c|c|c|}
\hline \multirow[t]{2}{*}{ Year } & \multicolumn{6}{|c|}{ Rice } & \multicolumn{4}{|c|}{ Wheat } \\
\hline & Punjab & $\mathbf{A P}$ & $\begin{array}{c}\text { Chhatti } \\
\text { sgarh }\end{array}$ & $\mathbf{U P}$ & Haryana & Comb & Punjab & Haryana & $\mathbf{U P}$ & Comb \\
\hline $1980-81$ & 45.12 & 12.43 & --- & 10.48 & 11.98 & 80.01 & 41.96 & 17.00 & 22.68 & 81.64 \\
\hline $1985-86$ & 42.70 & 15.94 & --- & 10.81 & 10.46 & 79.91 & 61.57 & 22.21 & 15.17 & 98.96 \\
\hline $1990-91$ & 38.05 & 26.32 & --- & 10.84 & 8.39 & 83.60 & 71.49 & 23.66 & 4.75 & 99.90 \\
\hline $1995-96$ & 34.46 & 36.64 & --- & 7.17 & 6.87 & 85.13 & 69.16 & 24.79 & 3.20 & 97.14 \\
\hline $1996-97$ & 32.77 & 34.89 & --- & 7.02 & 9.29 & 83.97 & 69.16 & 24.79 & 3.20 & 97.15 \\
\hline $1997-98$ & 38.86 & 24.73 & --- & 6.88 & 8.14 & 78.61 & 64.12 & 24.63 & 6.64 & 95.39 \\
\hline 1998-99 & 34.96 & 40.63 & --- & 6.89 & 2.38 & 84.86 & 48.58 & 24.96 & 16.92 & 90.46 \\
\hline 1999-00 & 37.39 & 30.16 & --- & 7.80 & 5.41 & 80.76 & 55.41 & 27.35 & 8.92 & 91.68 \\
\hline 2000-01 & 32.72 & 33.71 & 4.03 & 5.52 & 6.96 & 82.94 & 57.62 & 27.50 & 9.45 & 94.57 \\
\hline 2001-02 & 32.91 & 29.04 & 8.68 & 8.75 & 6.71 & 86.09 & 51.19 & 31.06 & 11.86 & 94.11 \\
\hline $2002-03$ & 48.34 & 16.05 & 7.86 & 8.28 & 8.07 & 88.60 & 51.85 & 30.90 & 11.07 & 93.82 \\
\hline 2003-04 & 37.94 & 18.53 & 10.40 & 11.19 & 5.84 & 83.90 & 56.57 & 32.42 & 7.68 & 96.67 \\
\hline 2004-05 & 36.89 & 15.82 & 11.49 & 12.04 & 6.73 & 82.97 & 55.02 & 30.46 & 10.37 & 95.85 \\
\hline $2005-06$ & 32.02 & 17.97 & 11.81 & 11.39 & 7.43 & 80.62 & 60.94 & 30.63 & 3.79 & 95.36 \\
\hline 2006-07 & 31.18 & 21.22 & 11.41 & 10.07 & 7.08 & 80.96 & 75.29 & 24.16 & 0.53 & 99.98 \\
\hline 2007-08 & 30.17 & 23.52 & 11.49 & 10.41 & 6.03 & 81.62 & 60.94 & 30.10 & 4.91 & 95.95 \\
\hline 2008-09 & --- & --- & --- & --- & --- & --- & 44.71 & 23.54 & 12.99 & 81.24 \\
\hline Mean & 35.51 & 25.52 & 9.65 & 8.85 & 6.67 & 82.99 & 57.80 & 27.88 & 8.33 & 94.02 \\
\hline $\mathrm{CV}$ & 13.33 & 30.56 & 26.13 & 22.97 & 24.82 & 3.15 & 13.95 & 10.93 & 51.99 & 4.62 \\
\hline
\end{tabular}

Note: Averages have been worked out for the period from 1996-97 to 2007-08/2008-09 
At the national level during 2005- 06 marketed surpluses of rice stood at $71.25 \%$ while of wheat at $54.90 \%$. Marketed surplus for rice for the major states contributing to the central pool stood as such - Punjab (98.12\%), Andhra Pradesh (79.99\%), Uttar Pradesh (38.93\%) and Haryana (96.82\%) while for wheat as such - Punjab (76.46\%), Haryana (66.24\%) and Uttar Pradesh (35\%). Thus both the marketing and procurement patterns for rice as well as wheat vary widely also among the major states

\section{Punjab State - Cropping Patterns}

Availability of assured marketing infrastructure and the irrigational facilities have heavily tilted the cropping pattern towards wheat during the rabi (summer marketing) while paddy during the kharif (winter marketing) season. An examination of (table 6) indicates that total cultivated area has in the state during the period 1992-93 to 2005-06 increased only marginally i.e. from 7.55 to 7.93 million ha showing an increase of $5.03 \%$ and it is higher to that at the country level (3.81\%). Cereals alone occupied $74.04 \%$ of the total cultivated area during 1992-93 that increased to $79.32 \%$ during 2005-06. Of this, combined share of wheat and rice alone stood at $70.86 \%$ that increased further to $79.05 \%$ during 2005-06. In comparison, cereals occupied $54.76 \%$ of the total cultivated area in

Table 6: Gross Cropped Area (million ha) across Various Crops during 2005-06

\begin{tabular}{|c|c|c|c|c|c|c|c|c|c|c|}
\hline \multirow[t]{3}{*}{ Crop } & \multicolumn{5}{|c|}{ India } & \multicolumn{5}{|c|}{ Punjab } \\
\hline & \multicolumn{2}{|c|}{$1992-93$} & \multicolumn{2}{|c|}{$2005-06$} & \multirow{2}{*}{$\frac{\text { Change }}{\%}$} & \multicolumn{2}{|c|}{$1992-93$} & \multicolumn{2}{|c|}{$2005-06$} & \multirow{2}{*}{$\begin{array}{c}\text { Change } \\
\%\end{array}$} \\
\hline & Abs & Share & Abs & Share & & Abs & Share & Abs & Share & \\
\hline Rice & 41.86 & 22.55 & 43.66 & 22.65 & 4.30 & 2.07 & 27.42 & 2.64 & 33.29 & 27.54 \\
\hline Wheat & 24.64 & 13.27 & 26.58 & 13.79 & 7.87 & 3.28 & 43.44 & 3.47 & 43.76 & 5.79 \\
\hline Jowar & 13.22 & 7.12 & 8.67 & 4.50 & 34.42 & --- & --- & --- & --- & --- \\
\hline Bajra & 10.85 & 5.85 & 9.66 & 5.01 & 10.97 & 0.01 & 0.13 & 0.01 & 0.13 & 0.00 \\
\hline Maize & 6.09 & 3.28 & 7.71 & 4.00 & 26.60 & 0.19 & 2.52 & 0.15 & 1.89 & -21.05 \\
\hline Others & 2.96 & 1.59 & 3.32 & 1.72 & 12.16 & 0.05 & 0.66 & 0.003 & 0.04 & -94.00 \\
\hline Coarse Cereals & 25.14 & 13.54 & 29.35 & 15.22 & 16.75 & --- & --- & 0.02 & 0.25 & --- \\
\hline Total Cereals & 101.65 & 54.76 & 99.72 & 51.73 & -1.90 & 5.59 & 74.04 & 6.29 & 79.32 & 12.52 \\
\hline Pulses & 23.57 & 12.70 & 22.33 & 11.58 & -5.26 & 0.10 & 1.32 & 0.03 & 0.38 & -70.00 \\
\hline Food grains & 125.22 & 67.46 & 122.05 & 63.31 & -2.53 & 5.69 & 75.36 & 6.32 & 79.70 & 11.07 \\
\hline Sugar cane & 3.93 & 2.12 & 4.65 & 2.41 & 18.32 & 0.11 & 1.46 & 0.08 & 1.01 & -27.27 \\
\hline Spices & 2.72 & 1.47 & 2.82 & 1.46 & 3.68 & --- & --- & --- & --- & -- \\
\hline Fruits & 2.84 & 1.53 & 3.89 & 2.02 & 36.97 & --- & --- & --- & --- & --- \\
\hline Vegetables & 4.17 & 2.25 & 5.43 & 2.82 & 30.22 & --- & --- & --- & --- & --- \\
\hline Oil Seeds & 26.75 & 14.41 & 30.92 & 16.04 & 15.59 & 0.19 & 2.52 & 0.08 & 1.01 & -57.89 \\
\hline Food Crops & 165.63 & 89.23 & 169.76 & 88.06 & 2.49 & --- & --- & --- & --- & --- \\
\hline Total & 185.62 & 100.00 & 192.78 & 100.00 & 3.86 & 7.55 & 100.00 & 7.93 & 100.00 & 5.03 \\
\hline
\end{tabular}


the country during $1992-93$ that declined to $51.73 \%$ during $2005-06$. However, combined share of wheat and rice in the cultivated area increased marginally from $35.82 \%$ to $36.44 \%$ during this period.

This indicates that the cropping pattern in the Punjab state compared to that in the country has turned highly skewed favouring the two crops wheat and paddy. As a result with emergence of monotonic cultural practices the state has come to face several environmental problems at the farm level. These include depletion in soil fertility and groundwater level, pest attacks, labour shortages particularly during the season, etc. The problem of depletion of groundwater level is particularly acute because paddy is a water intensive crop. Even though those farmers who can afford have installed submersible pump sets but it raises the costs of production. On the other hand, those farmers who have small and marginal sized holdings i.e. below four ha have come to face problems of financial crunch because of declining crop yields.

This has threatened not only the farmers' own food security but also the sustainability of agriculture. So, this necessitates that farmers should raise the alternative crops to bring shifts in their existing cropping patterns. However, poor farmers need access to specialized information, technology, professional knowledge, assets, institutions, infrastructure and credit to participate in growing global markets (IFPRI 2001). Information empowers the farmer with bargaining power against middlemen/traders who often have better access, can bring about stability in product supplies and prices over time and space and also throws light on the farmers' side where the buyers are (Adesina 2004). However, its availability in the developing countries/markets is characterized by asymmetry where a buyer/seller has more information than a person/firm on the other side of the transaction. For example, growers have better information on crops produced while processors on goods processed. This creates opportunities for them to behave in a strategic manner while affects the transaction costs for farmers by necessitating an access to the alternative and more expensive methods of communication such as frequent visits of markets. Due to the lack of formal contracts between the industry and farmers, farmers depending upon the availability of shipment facilities and the volume marketable surpluses dispose off their produce in the local/distant markets. So adequate local market information is a 
prerequisite but difficult to obtain (either does not exist, or not always accessible, or the telecommunication infrastructure is imperfect). And it depends largely upon the personal networks of the individual traders who are often reluctant to share it with the competitors (Lutz et al, 2000). Hence farmers have little access to information to combat uncertainty and enhance their participation in a fiercely competitive market environment. Thus imperfect information remains a major constraint on the potential market opportunities to interact on equal terms with the larger and stronger, market intermediaries (IFAD 2001).

An examination of the holding sizes (table 7) indicates that even though its overall size as well as for each individual category except the small sizes in the state is larger to that in India but its absolute size is not very large.

Table7: Status of Operational Holdings in Punjab and India

\begin{tabular}{lcccccc}
\hline & Marginal & Small & $\begin{array}{c}\text { Semi- } \\
\text { Medium }\end{array}$ & Medium & Large & Overall \\
\hline Punjab & & & & & & \\
Number ( '000) & 123 & 173 & 328 & 301 & 72 & 997 \\
& $\mathbf{1 2 . 3 4}$ & $\mathbf{1 7 . 3 5}$ & $\mathbf{3 2 . 9 0}$ & $\mathbf{3 0 . 1 9}$ & $\mathbf{7 . 2 2}$ & $\mathbf{1 0 0 . 0 0}$ \\
Area ('000 ha) & 78 & 242 & 876 & 1731 & 1096 & 4022 \\
& $\mathbf{1 . 9 4}$ & $\mathbf{6 . 0 2}$ & $\mathbf{2 1 . 7 8}$ & $\mathbf{4 3 . 0 4}$ & $\mathbf{2 7 . 2 5}$ & $\mathbf{1 0 0 . 0 0}$ \\
Average Size (ha) & 0.63 & 1.40 & 2.67 & 5.75 & 15.14 & 3.65 \\
India & & & & & & \\
Number ('000) & 75409 & 22696 & 14020 & 6577 & 1228 & 119930 \\
& $\mathbf{6 2 . 8 8}$ & $\mathbf{1 8 . 9 2}$ & $\mathbf{1 1 . 6 9}$ & $\mathbf{5 . 4 8}$ & $\mathbf{1 . 0 2}$ & $\mathbf{1 0 0 . 0 0}$ \\
Area ('000 ha) & 29815 & 32144 & 38192 & 38215 & 21070 & 159436 \\
& $\mathbf{1 8 . 7 0}$ & $\mathbf{2 0 . 1 6}$ & $\mathbf{2 3 . 9 5}$ & $\mathbf{2 3 . 9 7}$ & $\mathbf{1 3 . 2 2}$ & $\mathbf{1 0 0 . 0 0}$ \\
Average Size (ha) & 0.24 & 1.42 & 2.39 & 4.42 & 13.16 & 1.33 \\
\hline
\end{tabular}

Source: Website of Agricultural Census Division, Ministry of Agriculture, New Delhi.

In addition, studies have indicated that human assets of the farmers particularly the educational level remains low in the state (Goel and Kaur 2008, Goel et al 2004). This implies that farmers on their own are reluctant as well as incapable of bringing shifts in the cropping patterns. This is because open markets expose them to higher market risks such as price and sales uncertainty, higher transaction costs, market thinness, etc. For example, under the Sir Ratan Tata Project in the selected districts of the State and selected farmers were distributed seeds for the alternative crops as an experiment. Farmers were asked to raise groundnut crop in the Sangrur district. Farmers were 
satisfied with its yield as well as the market price but faced difficulties in its marketing. In the wholesale food grain market commission agents were not very keen in handling this crop for the client farmers. This was because the number of buyers was fewer and they entered the market infrequently so this added to the costs of supervision. At the industry level, oil crushing units have already been closed since the setting up of rice shellers during the Post liberalization Period. So, buyers for this crop were mainly vendors/roasters who bought it particularly during the winter season. This is because roasted groundnut is consumed as a snack during this season that lasts for about four months. So, farmers had to sell groundnut either from the roadsides in the adjoining towns or ship it to Ludhiana district (Goel et al 2004). Farmers were asked to raise maize crop in the Nawanshahr/Hoshiarpur districts. Maize pods are consumed either as snack or pancakes (as a delicacy along with saag prepared from mustard leaves) are prepared from its flour particularly during the winter season. Commission agents in the markets for food grains faced difficulties in selling this crop because of fewer buyers, smaller lot sizes and varietal variations. Rather, traders/millers turned to the major markets for wider product selection choices. Some farmers in the Hoshiarpur district at their individual levels raised maize crop for pop corn. They faced difficulties in selling it even to vendors. This was because vendors in their mind sets have a strong feeling that the quality of maize used as pop corn grown elsewhere is superior.

\section{Conclusion}

Poverty continues to persist high and varies across regions. It is predominantly rural in nature. PDS constitutes a key element of food security in the country. With the adoption of green revolution technology domestic production of the major cereals i.e. wheat and paddy has increased many fold. As a result, country has come to rely upon internal procurement to meet its requirements for national food security. Supportive conducive policy framework for the major crops has tilted the cropping pattern in the country in favor of these crops. However, in the state of Punjab a major contributory to the national pool for these crops cropping pattern has been heavily slanted towards both these crops. As a result, the state has been confronted with several environmental problems. Factors such as small holding sizes, low educational levels of farmers and the lack of adequate market infrastructure for the alternative crops that add to their 
transaction costs discourage them to bring large-scale shifts in their cropping patterns. Rather, they continue to rely upon paddy cultivation which they still find comparatively more remunerative. This indicates that farmers in the developing countries are on their own are unable to take bold initiatives to integrate their cropping patterns with the markets. This may threaten their own future security add a new dimension to it.

\section{References}

Adesina, A. 2004 Making Markets Work for the Poor in Africa, paper personated at the Presidential-Level Seminar on Innovative Approaches to meeting the Millennium Hunger Development Goal (MDG) for Africa, July 5, United Nations Conference Centre, Addis Ababa, Ethiopia, www.ifad.org

Antony G. M. and A. Laxmaiah. 2008. Human Development, Poverty, Health and Nutrition Situation in India, Indian Journal of Medical Research. 128 (August): 198-205

Barun, J.V et al. 1992. Improving Food Security of the Poor: Concept, Policy and Programmes, International Food Policy Research Institute, Washington, D.C.

Food and Agriculture Organization. 2006. The State of Food Insecurity in the World, ftp.fao.org

Food and Agriculture Organization. 2000. The State of Food and Agriculture, Rome.

Food and Agriculture Organization. 1996. Food for All, Report prepared on the occasion of World Food Day Summit, $13^{\text {th }}-17^{\text {th }}$ November

George, P.S.1999. Some Reflections in Food Security in India, Indian Journal of Agricultural Economics, 54 (4)

Goel, V. 2009. Poverty and the Food Security Scenario in India, paper presented at the National Seminar on Emerging Challenges in Agriculture, Feb., $18^{\text {th }}-19^{\text {th }}$, Chandigarh.

Goel,V and I. Kaur. 2008. Strategic Role of Trade Credit in Chain Coordination for the Traditional Farm Business Enterprises in Punjab, India, International Journal of Food and Agribusiness Management, 20 (2): 33-60.

Goel, V, M.S.Toor and V. K. Sharma. 2004. An Economic Analysis of Rice-Wheat Cropping Systems and its Potential Alternatives, Research Report, Department of Economics and Sociology.

Government of India (GOI). 2002. Tenth Five-Year Plan, Planning Commission

Government of India (GOI). 2007. Poverty Estimates for 2004-05, Press information Bureau, New Delhi, www. planningcommission.nic.in 
Hulse J. H. 1999. Food Security for Urban Families edited by C. Tacoli. Livelihood Strategies across the Rural-Urban Divide, in Policy Matters: Sustainable Livelihoods, Newsletter of the IUCN Commission on Environmental, Economic and Social Policy. Issue No. 5.

Hulme, D., K. Moore and A. Shepherd. 2001. Chronic Poverty: Meanings and Analytical Frameworks. CPRC Working Paper No. 2. University of Manchester, Manchester.

International Food Policy Research Institute 2001. Sustainable Food Security for All by 2020. Draft.

Joshi P.D. 1997. Conceptualisation, Measurement and Dimensional Aspects of Poverty in India, paper presentated at the seminar on Poverty Statistics, $7^{\text {th }}-9^{\text {th }}$ May, Santiago.

International Fund for Agricultural Development (IFAD), 2001. Markets for the Rural Poor, chapter5, Rural Poverty Report, www.ifad.org

Lutz, C. et.al. (editor). 2000. Food Markets in Burkina Faso, CDS Report No. 10, ISSN 1385-9218, December, www.rug.nl

Masika R., A. de Haan and S. Baden.1997, Urbanization and Urban Poverty: A Gender Analysis, Swedish International Development Cooperation Agency (Sida), Institute of Development Studies Report No 54, ISBN 185864347 3, www.bridge.ids.ac.uk

Ministry of Agriculture. 1994. Report of Working Group on Foodgrains Requirements by the year 2000 AD. New Delhi.

Nawani N.P. 1994. Indian Experience on Household Food and Nutrition Security, FAO Report Regional Expert Consultation, FAO-UN, Bangkok

OECD. 2000. Supplement 2: Food Security and the Role of Domestic Agricultural Production. Paper presented at the International Conference on Non-Trade Concerns in Agriculture in Ullensvang, Norway, 2-4 July, www.oecd.org

Prakash, S. and V. Goel. 1986. Regional Inequalities of Agricultural Development in India, w.r.t. the Output of Food grains, The Economic Journal of Nepal, 9 (3): 1-21

Pretty, J. N., J. Thompson and F. Hinchcliffe. 1996. Sustainable Agriculture: Impacts on Food Production and Challenges for Food Security. Gatekeeper Series No.60, Sustainable Agriculture Programme. IIED: London.

Radhakrishna, R. K., H. Rao, C Ravi and B. S. Reddy. 2007. Estimation and Determination of Chronic Poverty in India: An Alternative Approach, August, CPRC Working Paper 90, www.chronicpoverty.org 
Scherr, S. 1995. Improving Natural Resources to Feed the World: Prerequisites for Sustainable Agriculture, Speech at the International Conference on a 2020 Vision for Food, Agriculture and the Environment. IFPRI: Washington, DC.

Singh, S. 2006. Food Security: Effectiveness of the Public Distribution System in India, Master's Thesis, Faculty of Economics and Centre for Promotion of Enterprise, University of Ljubljana, Gwalior

United States Department of Agriculture (USDA). 1998. Food Security Assessment: Situation and Outlook Series, International Trade and Agriculture Reports, GFA-10, December 